\title{
Grace Lees-Maffei
}

\section{Chapter 7: Hospitality and Home}

\section{British and American Cultures of Entertaining}

\section{Introduction}

\section{Domestic privacy and the history of the home}

The eighty years from 1920 to 2000 saw tremendous changes in the ways that hospitality was practiced in people's homes, informed by simultaneous shifts in class, increased home ownership, informalization, the development of the hospitality industry, greater media attention paid to the home, and changing perceptions of domestic privacy. Today, we think of the home as private, a place in which to retreat from the public sphere, at least in the West. Sure, we invite friends and extended family into our homes. We practice our hobbies at home, with or without others, and work at home, too, domestically and more formally. But, these diverse uses of the home do not obscure the fact that the contemporary home is our space to control. This was not always the case: the perceived, and actual, privacy of the home has waxed and waned over time.

Medieval and early modern households were small communities working together and living together. They accommodated immediate and extended family, staff and retainers of various kinds such as apprentices. Rather than the entire home being perceived as a private space, therefore, medieval householders attributed varying levels of privacy to particular rooms or spaces. The view of the home as a private place more generally intensified in the West in the nineteenth and twentieth centuries as the notion of a household became more firmly associated with the immediate family only. In the Victorian period, room usage became more specialized so that separate morning rooms, dining rooms, parlors, sitting rooms, billiard rooms and smoking 
rooms were variously found in homes of different scales. These differentiated rooms managed sociability in the home so that the remaining rooms — and the home over all—was increasingly perceived as a private realm. This model of domesticity continued throughout the twentieth century. In the current century, however, the physical privacy of the home is compromised by online social interactions. It is no longer accurate to consider the home a private place; Western children, for example, are as vulnerable to bullying and abuse from school peers within their homes via social media as they are in the school playground. Even though such online interactions increasingly challenge domestic privacy today, the home is still represented as a private place and a refuge.

In fact, the very privacy of the late modern home has made it hard for historians to access. What we know about homes of the past is limited by the lack of historical sources which in turn results from varying ideas about what is, and has been, important. For these reasons, the home has long been ignored by historians. However, that situation has now altered and the economic, political, social and cultural significance of the homes of the past is increasingly recognized. If information about past homes is hard to find, there is a wealth of information available in books of domestic advice. These books offer us insights into the "real ideals" (LeesMaffei 2013: 51) that readers bought in to when they purchased, and read, them. And they tell us, if not what actually went on in people's homes, then what notions of acceptable and aspirational hospitality at home were shared by advisors with their readers. When we read domestic advice books accordingly, as fictions to which home dwellers have aspired —or not— we can understand what was possible and desirable in domestic hospitality, and what was not.

\section{The literature of hospitality: Domestic advice books}


Domestic advice literature has a long history. Historical sociologist Norbert Elias traces the roots of twentieth-century advice books back to Greco-Roman antiquity, and even earlier (1994 [1939]). Some of the earliest advice books addressed children and behavior at royal courts, with a notable example being Erasmus of Rotterdam's De civilitate morum puerilium (on civility in children), of 1530 (Elias 1994 [1939]: 42-3). The form and content of advice literature, as a discourse that mediates between society and the individual, have been shaped in response to social and cultural changes throughout the modern period (Lees-Maffei 2013: 31). Elias's focus is on guides to manners, specifically, and these have much to tell us about how people behaved in their homes, as well as outside the home. But we can add to that corpus of writing the other literatures of domesticity. Early cook books, for example, are important forerunners to the domestic manuals of the twentieth century. Domestic advice literature first developed from its roots in guides to courtly life, books on husbandry and housewifery, and recipe books, to holistic texts on domestic economy, akin to the catch-all nature of the almanac. The genre of domestic advice literature has undergone increasing specialization as those general household guides divided into guides for ladies and for gentlemen, manuals on housewifery and husbandry, books on home decoration, which guide readers in constructing their domestic spaces, and books about home entertaining, which cover cookery, and the creation of a hospitable environment. To understand hospitality in the past, it is useful to read three specialized and differentiated subgenres: etiquette books aimed at harmonizing social interaction, homemaking books concerning the establishment and maintenance of homes, and home decorating books which have guided readers in the design of their homes.

As well as becoming more specialized so that its constituent categories multiplied, in the twentieth century domestic advice literature was published in greater numbers of titles and in an 
increasingly wide range of formats. During the postwar period, domestic advice literature expanded across the cultural and literary landscape, aided by increased literacy and affluence, cheaper formats such as paperbacks, increased choice in consumer goods as a result of developments in manufacture, distribution, marketing, advertising and retailing, social developments that created an extended market for advice and cultural developments including lifestyles and the aestheticization of everyday life. Perceptions of increased social transition, and increasingly rapid shifts in behavior produced a significant market for domestic advice

\section{Gender roles in the home}

The market for domestic advice has been largely female, because the association of woman and home is fundamental in Western patriarchal society. In the post-Second World War period, girls were given conduct manuals and brides received household manuals and etiquette books. Although men are stereotypically associated with home building, DIY and home maintenance, home decorating guides have also been aimed at women. The stereotypical roles for men and women in our society have been reflected in the advice books written for them, with very few changes over the period from 1920 to 2000 . Sexism pervades the literature of hospitality and the roles assigned to women and men in the practice of home entertaining (Lees-Maffei 2007). Women and men performed distinct roles on a day-to-day basis in the home, and when guests came to visit. In families with domestic staff, the lady of the house would oversee the food and accommodation; every aspect of the experience would be her responsibility even if she did not actually do the physical domestic labor. In families without staff, typically a woman undertook the cooking, cleaning and presentation of the home for hospitality.

Children are not mentioned as playing a role in domestic hospitality unless it is their friends, rather than their parents' friends, who are visiting. In that case, children and teenagers 
are encouraged to assist with the preparations for home entertaining, or even to take full responsibility for it, in consultation with their parents. Many post-Second World War domestic advice guides, which address issues arising from the demographic increase in teenagers and their increased prosperity, relative to their parents, complain about the lack of assistance offered by children around the home, especially when friends visit (Lees-Maffei 2013: 151-60).

Men's role in home entertaining has traditionally been to provide drinks and carve the meat. However, the host remains a key figure particularly if we understand him, as sociologist Thorstein Veblen suggested, as the provider (Veblen 1970 [1899]). Veblen observed the status accruing to the male head of the household as he, and the people around him, engaged in conspicuous consumption of his wealth. So a wife providing a luxurious meal is making use of his resources. A guest enjoying an aperitif given to her or him by the host is also conspicuously consuming the host's wealth. Home entertaining, in these terms, becomes an expression of the host's wealth and status.

\section{Democratizing hospitality: Interwar hospitality at home, 1920-1939}

In post-industrial Western society, aristocratic authority has diminished, and so has the role of aristocrats as tastemakers. In the United States, models of hospitality ceased to follow French and British courtly models from the 1820s onwards (Schlesinger 1968 [1946]; Lynes 1980 [1949]: 5). In Britain, a feudal hierarchy in which power resided with a land-owning aristocracy persisted until the 1870s. Between the 1880s and the 1930s, however, the dispersal of the great estates, comprising a great house, gardens, parks and extensive land, unlocked a triangle of power, prestige and property (Cannadine 1990: 18, 343), while the sale of titles and honors allowed new money into high society. Plutocrats, such as the press barons Lord Beaverbrook and Lord Rothermere "lived far more loudly, lavishly and, luxuriously than the patricians, and [...] 
increasingly set the social tone" (Cannadine 1990: 345). At the same time, an influx into British high society of foreign-born brides — especially the tenfold rise in American peeresses between 1880 and 1914 (Cannadine 1990: 347)—further functioned to relax conventions.

In the United States and the UK alike, the twentieth-century middle class was swelled by a newly affluent portion of the working class. ${ }^{1}$ Describing this expansion, British sociologist Anthony Giddens (1981: 111-197) popularized the term "new middle class." For Giddens, lifestyle choices have become increasingly central to the construction of social identities (Giddens 1991: 50). This newly expanded middle class presented new problems of hospitality at home on both sides of the Atlantic related to the relative unavailability of resources including time, staff and resources, when compared with their upper-middle and upper-class models of hospitality. Domestic advisors recommended scaled-down, cheaper, modes of home entertaining suited to middle class, rather than upper class, elite, or aristocratic lifestyles. Indeed, domestic advice itself can be seen as a middle class cultural form: "the very profusion of etiquette books, their large sales, and the insistent flow of collateral advice in periodicals suggests a demand for and preoccupation with gentility among middle class people" (Ohmann 1996: 152-3), while new broadcast media such as television disseminated education and entertainment across the population, whatever the social class.

In the UK and the United States, during the period between the two World Wars, Victorian domestic hospitality practices persisted. The domestic hostess was still presented as a conspicuous consumer of her husband's wealth and status, and of the great number of goods and

\footnotetext{
${ }^{1}$ From 1911 to 1981, white-collar workers rose from less than 14 percent of the British working population to 43 percent. In the United States between 1900 and 1980, they increased from 17.5 to 52 percent (Edgell, 1993: 66), reaching perhaps as much as 70 percent (Goldthorpe et al 19689) of American society.
} 
services that formed her home, including the labor of her staff (Veblen 1970 [1899]: 68). Before the Second World War, the ideal hostess depicted in domestic advice was seemingly disengaged in her demean our (Lees-Maffei 2007) as shown in The A.B.C. of Etiquette by a Society Lady of 1923, published a year before economist Thorstein Veblen's Theory of the Leisure Class first appeared in Britain:

When receiving callers, it is necessary that the lady should rise or lay aside the employment in which she may be engaged [...] The duties of hostess at dinner are not onerous; but they demand tact and self-possession in no small degree. She does not often carve. She has few active duties to perform; but she must neglect nothing, put all her guests at their ease, and pay every possible attention to the requirements of each and all around her. No accident should ruffle her temper. No disappointment ought embarrass her. She ought to see her old china broken without a sigh, and her best glass shattered with a smile (A Society Lady, 1923: 38).

Here the hostess's success in hospitality is dependent upon her skill in "emotional labor" (Hochschild 1983; James 1989), meaning her attentiveness to others and suppression of her own reactions. Her only apparently active role is symbolic, as exemplified by the practice of the formal procession to the dining room, which was as much about status hierarchies as it was about moving guests from one room to another. Dinner parties would have begun with drinks in the drawing room, followed by a formal procession to the dining room for a meal of five or more courses, after which the ladies withdrew (to the withdrawing, or drawing, room) leaving the men to their own amusements for a while. The men's activities might involve cigar smoking, games such as billiards, and conversations not thought suitable for the ladies. The ladies would subsequently rejoin the gentleman. Doyenne of American manners, Emily Post, illustrates "The 
perfect example of a formal dinner table of wealth, luxury and taste" in her "Blue Book" of Etiquette, first published in 1922, noting that it "involves no effort on the part of the hostess of a great house beyond deciding upon the date and the principal guests who are to form the nucleus of the party (Post 1922: caption to plate between pp. 236-7) [Figure 7.1 near here]. Post here overstates the hostess's lack of involvement, perhaps to underline the staffed grandeur with which some members of society entertained. Although the hostess was relatively uninvolved in the overt labor of hospitality, her guests would have held her responsible for every aspect of their experience.

The A.B.C. of Etiquette offers remarkably similar advice to guests as it does to hostesses and hosts: "Should you break or upset anything, do not apologies for it. Show your regret by your facial expression. It is not considered well-bred to put it into words" (A Society Lady 1923: 36). Veblen observed that the guest "consumes vicariously for his host at the same time that he is a witness to the consumption of that excess of good things which his host is unable to dispose of singlehanded" (Veblen 1970 [1899]: 65). Guests and hostess each consumed the host's wealth. At the highest levels of what Veblen termed the "leisure class," the host, as the male head of the household, also engaged in conspicuous consumption of his staff's labor and he, like his female counterpart, had very little to do, except perhaps carve meat. In this situation, the lack of active labor on the host's part, and his leisure, communicates status.

If the hospitality shown in interwar advice literature emphasized disinterested leisure for the host, hostess and guests, it was extremely labor-intensive for staff. From 1920 to 1939 , domestic advice writers continued to assume that their readers would have domestic staff, whether permanent or employed for specific occasions. During wartime, and in the postwar period, such an assumption became untenable, and domestic writers addressed both staffed and 
unstaffed households or, increasingly, solely the latter. However, a pre-Second World War ideal of leisurely hospitality based on social ease persisted. Even as late as 1959, sociologist Erving Goffman emphasized the social importance of the hostess's "secret consumption" and hidden, "backstage" labor (Goffman 1990 [1959]: 39). Labor is secret and hidden in order to maintain the illusion of ease associated with an aristocratic model of status.

Early efforts at rationalizing the burden of the homemaker without staff began with increasing specialization of kitchen design. Historian Ian Bullock has noted that the development of gas-powered lighting and cooking allowed the separation of food preparation from living quarters, and the subsequent replacement of the "living kitchen," celebrated by architect and author Herman Muthesius among others, with the "cooking kitchen" (Bullock 1988). The cooking kitchen bore the influence of "New Housekeeping" advocate Christine Frederick, whose Household Engineering (1919) appeared in Britain in 1923. Influenced by Frederick, Grete Schütte-Lihotzky designed what has commonly been regarded as the first fitted kitchen for the Frankfurt am Main housing settlements created by city architect Ernst May in 1926, in which cooking equipment and supplies were readily at hand and no extraneous activities were accommodated (Henderson 1996). In the rationalized domestic spaces designed by Frederick and Schütte-Lihotzky, the wife — and despite the fact that women were increasingly working outside the home, gender roles within the home remained traditional — acted both as hostess in the "front-region," or public space, of the home, and as domestic worker in the "back" or off-stage region, where the unseen labor of cooking took place. Thus, while Frederick, Schütte-Lihotzky and their followers attempted to rationalize and make easier household work, they failed to address the fact that in performing the conflicting roles of both entertaining guests and cooking, the unassisted hostess was simultaneously expected to perform in the front and backstage regions 
of the home (Goffman 1990 [1959]: 110, 114). Distinct from the solutions produced by followers of Frederick's New Housekeeping, were a range of solutions dependent not upon rationalization, but rather upon the informalization of domestic practices. What has been accepted today as common sense may for hostesses of the interwar and postwar periods have seemed to fall short of proper hospitality.

\section{Second World War hospitality, 1939-1945}

In the UK, aristocratic influences on the ways in which hospitality was practiced and expressed waned between the wars and disappeared completely during the Second World War. Grand houses were requisitioned for use as hospitals and other institutions. Food and cooking ingredients were severely rationed, as were fabrics, clothes and furniture. What was available often differed considerably from interwar market offerings, so that shop-bought eggs were replaced with powdered eggs, and fashionable clothing was replaced with "Utility" scheme options that echoed the simple geometric aesthetic of military uniforms. The British government's Utility scheme aimed to provide economical clothing and furniture which used the minimum of materials while also being well made and hardwearing. Utility furniture introduced a reluctant British buying public to the clean lines of continental modernist design [Figure 7.2 near here]. Wartime rationing did more than reduce the options available to those wishing to entertain others at home: it also had a levelling effect. Ministry of Information propaganda campaigns in the UK warned against waste of food and other resources through the figure of the Squander Bug, while the notion that "careless talk costs lives" was promoted in order to regulate sociability and keep gossip in check. The Ministry of Food, under Lord Woolton, worked to improve health during the Second World War through the provision of canteens, civic "British restaurants" and meals in schools as well as through rationing and price controls to guide eating 
and nutrition education. In fact, eating out, rather than at home, increased from 79 million meals per week in 1941 to 170 million by the end of 1944, and the transformation "shifted a quarter of the average individual's leisure time away from the home" (Hardyment 1995: 10).

The question of how to express hospitality at home when faced with the challenges of war and associated rationing taxed domestic advice writers and householders alike. However, more positively, rationing, patriotism and a desire to succeed during wartime deprivations produced a strong commitment to thrift, ingenuity and keeping up appearances. Truly skilled hosts and hostesses could make their guests feel indulged notwithstanding wartime deprivations, advisors reassured their readers. "Victory pudding" made a virtue of necessity, comprising "eggless sponge plumped out with grated carrot, potato and breadcrumbs" (Hardyment 1995: 11). Constance Spry's 1942 book Come into the Garden Cook was part of a trend for kitchen gardening in order to supplement rationed food, while Marguerite Patten guided 18 million radio listeners to "The Kitchen Front," a daily dose of food and cooking advice. In addition, the war brought people together in ways that would not have occurred during peacetime. From the crowded bomb shelters and London Underground stations of the air raids, to communities pulling together to host social events in spite of wartime conditions, camaraderie was given a boost by the very unusual circumstances.

Margaret Merivale's interwar home decorating book, Furnishing the Small Home of 1938, begins with a letter to the reader, addressed "Dear Virginia..." Virginia is shown to have expressed an interest in homemaking advice for people on reduced incomes (Merivale 1944 [1938]: 5). Merivale's solution is fashionable, modernist design. "In just the same way that you would not think for one moment of wearing a hat bought fifty years ago, you must not collect Victorian atrocities if you are furnishing a modern home." She goes on "I want you to see what 
is of our own times in furniture and accessories, and to consider their merits in the light of today's requirements" (Merivale 1944 [1938]: 5). However, the 1944 edition has the following postscript:

My letter to you was written in the spacious days of peace, and now we are at war your choice is temporarily much more limited $[\ldots]$ and if you cannot furnish as you wish immediately, I hope my book will help you to weave the picture of the ideal home which you are going to have when the war is won. You will not only be very patriotic but very wise if you confine your purchases to absolute essentials. In war-time, the choice is restricted, labor is scarce, and prices are bound to be high. Many of the items shown here will not be obtainable to-day, but they will help you formulate your own ideas (Merivale, [1938] 1944: 15).

Merivale presents the war as beneficial for introducing new design "developments in plastics, glass and metals" and concludes "Weave your dreams with the aid of this book: work out your plans; then when the time comes, you will be ready to complete your scheme..." (ibid.). Dining room solutions include a dining cabinet, from which a table pulls out and, using an idea from Sweden "a dining alcove, enclosed by draperies of striking design" (Merivale 1944 [1938]: 50). The setting for domestic hospitality during the Second World War was complicated by the fact that for many people in Western Europe at that time, their furniture was destroyed as homes were routinely bombed. The need for furniture was increased by relocation as well as bombing. In Britain, the government's Utility Furniture scheme (explained above) catered for the wartime mass market as far as possible within the constraints of manufacturing and materials shortages. Utility furniture, like Utility garments and rationed food, was purchased with rationing coupons. The furniture was economical with materials and labor. Utility design was informed 
both by the design reformers of the nineteenth century and by continental modernism, and it was offered to consumers who had little alternative. While Norman Hartnell's Utility clothing enabled the whole country to be dressed in patriotic quasi-militaristic styles by the Queen's dressmaker, Utility furniture has been seen as a route through which a British public notoriously resistant to continental modernism was persuaded to accept a pared-down practical aesthetic (Lees-Maffei 2010: 131). In Britain, rationing continued until 1954, so that the privations of war continued well into the postwar period, notwithstanding its much-vaunted optimism, Americanization and consumerism.

\section{Postwar hospitality, 1945-1959}

The impact of conflict continued to be felt in the home following the Second World War as the Cold War replaced the frontline carnage of trench warfare and the air raids of the First and Second World Wars with newly developed nuclear weapons. These were largely kept on standby rather than being detonated, their symbolic threat fueling a war of competing ideologies in which socialism and capitalism, as represented by their respective leaders, the Soviet Union and the United States, sought to gain global dominance. The quality of life experienced by ordinary people became highly politicized, with each superpower seeking to show that it offered superior living standards. Cultural historian Susan Reid has shown that the Cold War was fought as much through public debate about the domestic interior as it was through the space race. Scientific communism was embedded in household advice, domestic science education, rational planning of the kitchen or "scientific management," and the domestication of the scientific-technological revolution through the mechanization of housework (Reid 2005). The home was a crucial tool in the armory of ideology and iconography, whether directly-for example in the flexible and space-saving furnishings developed to meet the needs of citizens of the new apartment blocks 
showcased by Soviet city planners - or indirectly, from the space-inspired fashion of Frenchman Pierre Cardin to the application of new materials in furniture and interior design. The latter is exemplified by the fiberglass chairs of leading American designers Charles and Ray Eames, and the anonymous pattern designers at Formica (Lees-Maffei 2010: 132).

Key determinants of hospitality at home during the period following the Second World War included economic changes that allowed greater employment opportunities to women. While working-class women had always worked, a new job market offered them alternatives to domestic service, thereby transforming both their lives, and the lives of those they had served. In postwar Britain even women in a position to afford full-time live-in domestic assistance sometimes experienced difficulty finding staff (Lees-Maffei 2007). Writing of the United States, Susan Strasser notes that domestic service was never as prevalent as "the literary evidence" suggested and that "people of limited means_-that is, most people-employed household help [only] in emergencies" (Strasser 2000 [1982]: 164-5). A shift "from service to self-service" impacted upon both those members of the middle classes who needed to revise their domestic practices as a result of losing their staff and a new group of socially mobile readers keen to entertain in a manner different to the one they had known at home (Lees-Maffei 2001). The latter group might be, for example, those brought up within working-class cultures who sought to participate in the newly enlarged middle class.

So in this period, when women managed work inside and outside the home in evergreater numbers, advisors suggested that the work of hospitality should be distributed among the guests. A clear example from the period is American industrial designers Russel and Mary Wright's Guide to Easier Living (1950, revised 1954). The Wrights' book shows that far from dispensing with a need for published advice, informalization necessitated what they termed "the 
New Hospitality." They recognized that "we live in a transition period in which there are few established rules" (Wright and Wright 1954: 187). Their introduction rails against the "Old Dream" of gracious living inherited from "the stilted ritual of the English manor house": "Subtly preached by that able evangelist Emily Post, the Dear Old Dream dominates writing and merchandising concerned with the home, haunts domestic architecture across the country, and tyrannically rules American family life" (1954: 2). The Guide to Easier Living was as important as Russel Wright's tableware designs in prompting curators Donald Albrecht and Robert Schonfeld to assert in 2001 that "more than their fellow modernists Charles and Ray Eames or George Nelson, the Wrights influenced the postwar home in an all-encompassing way" (Albrecht and Schonfeld 2001: 19). Russel Wright began his career designing for the theatre, like Norman Bel Geddes, for whom he worked as an apprentice, and this training may have influenced the way he sought to design domestic behavior as well as household goods. A retrospective at the Cooper-Hewitt National Design Museum in New York in 2001 sought to communicate "both the formal and social dimensions of Russel and Mary's work, from individual objects to scripts for entertaining," and presented their interior design, landscaping and architectural output as "Stage Sets for American Living" (Albrecht and Schonfeld 2001: 21). But while they were explicitly engaged in scripting "the new hospitality," Mary and Russel Wright tried to sidestep the paradox of replacing one set or rules with another: "Once you've shaken free of traditionalism, don't, for heaven's sake, go looking for a new type of Dream House, or for a new Emily Post to put yourself in bondage to. Don't swallow anyone's ideas whole, not even the ones in this volume" (Wright and Wright 1954: 9).

Aspirations to informality are particularly highlighted in the act of home entertaining, which not only requires a considerable effort on the part of the hostess and/or host, but also 
demands that such effort be concealed or denied, for the avoidance of embarrassment (guests feeling discomfited by their friends serving them). Wouters' argument that informal interactions require more internalized labor for the individual, discussed at the start of this chapter, has a parallel in the extent to which informal patterns of home entertaining have not diminished the work of the hostess and/or host, but rather forced it into hiding, under the pretense of nonchalant ease. As Mary and Russel Wright state, apparently without intended irony: "We can plan for that informal, relaxed kind of entertaining" (Wright and Wright 1954: 166). Although the authors would probably deny it, their book shows that, because it is undertaken without hired help, entertaining informally is no less demanding of the hostess and/or host than earlier formal models. Their emphasis is on planning and simplification ("perhaps the most important consideration of all in the new etiquette") of both menu and service: "We believe that your degree of nonconformance to useless convention determines the extent of your meal's smooth service, plus meaning less work for you. Any of these simplifications, if executed thoughtfully, can be in good taste, can even have 'style"' (Wright and Wright 1954: 167, 169).

The Wrights' recommendations for informal hospitality included "the Kitchen Buffet" ("quite the most unconventional and informal variation, if your kitchen is large enough to permit it") and a T-shaped setting termed "the Cafeteria Table." The latter is described as "a worksaver for family meals; it is easily adapted to company meals," in which guests move along the short side of a table collecting flatware, plates, bread, butter and a drink and then sit down at the long sides of the table to help themselves to food set in the middle (Wright and Wright 1954: 173, 174). This recommendation is followed by a chart in which the eighty-two items carried to and from the table for a conventional setting are compared with the thirty-six pieces needed for the "Cafeteria" setting. So the designers of "by far the best known [tableware] in the country" (as 
claimed on the flyleaf for Guide to Easier Living) were influential in the art of doing without unnecessary table items.

By the 1950s, service hatches were a feature of new homes and a commonplace improvement in old ones. Like the "dumb waiter" lift between floors of a home, the hatch physically connected the backstage kitchen and the social parts of the home. It saved steps, obscured labor or its material evidence in the kitchen from guests, and "catered to the growing feeling that it was somehow not quite right for mum to be shut away in the kitchen" (Hardyment 1995: 57). In subsequent decades, hatches did not disappear through disuse; rather they were incorporated into more ambitious architectural solutions such as the kitchen-diner and open-plan living solutions. Howard Robertson's Reconstruction and the Home of 1947 shows an interwar example of a hatch built in to a storage unit dividing kitchen and dining room, called a "buffetdresser fitting" (Robertson 1947: 31-2). Mary and Russel Wright's Guide to Easier Living presented similar open hatch solutions, allowing greater interplay between food preparation and dining areas. One image from the Walker Art Center's Idea House II—built in Minneapolis, Minnesota in 1947—shows a peninsular breakfast bar, which allows serving directly from the kitchen and easy return of crockery, although it was probably not intended for anything other than family dining, as the seating is in a linear rather than conversational arrangement.

On a larger scale, the fashion for open-plan interiors and zoned living preoccupied postwar architects, interior designers and domestic advice writers. There is little scope for the cover and refuge provided by a backstage environment in a kitchen-diner, a bedsitter or a home with few internal walls. For the Wrights, these open environments necessitated new forms of entertaining: "Who would think about wearing an evening gown on the golf course? Isn't it just about as ridiculous to set a traditional table, complete with starched white damask and all the 
trimmings in the dinette, or in a combination living-dining room?" (Wright and Wright 1954: 189). They recommend enlisting help from guests, so that whether in conventional homes with clearly demarcated front and backstage spaces, or in homes where front and backstage are collapsed, guests will find their way into the kitchen, thereby necessitating new etiquette [Figure 7.3 near here]. As an example of "present-day good manners," the Wrights cite the importance of hostesses/hosts cleaning up after meal preparation and before guests arrive, so if a guest offers to help with the post-meal cleaning, you “don't inflict your unwashed before dinner pots and pans on them" (Wright and Wright 1954: 171). Whatever the material makeup of the home in which hospitality was to take place, hostesses or hosts were encouraged to set the scene with care, considering everything in the home as evidence of their personalities, and therefore as being of potential value in supporting their hospitality (Lees-Maffei 2007).

\section{Hospitality at home in the swinging sixties, 1960-1970}

Solutions to the problem of hospitality without staff at home ranged from changes in the food served, the methods of serving, the transportation of food between regions of the home, and the locations for the service of food, as well as in the practice of allowing guests to assist, as discussed above. The period from 1960 to 1970 saw some of the most innovative approaches to lessening the labor of hospitality through the design and architecture of the home.

Public health scholar John Coveney has noted: "During the 1950s and 1960s 'convenience' foods were increasingly promoted as cooking in the 'modern' way" (Coveney 2000: 133). These relied on a number of developments which occurred during the first half of the twentieth century: increased production capacity, the availability of dietary supplements and vitamins, the consolidation of supply into multiple retailers and the importance of refrigeration technology for the types of foods sold, their distribution and domestic storage. Additional 
advances in branding, marketing and packaging foods were aided by emergent materials and techniques such as cellophane and canning and by the development of television advertising from 1955 onwards (Oddy 2003). Supermarkets proliferated during this decade. The demographic shift towards smaller households and, in Britain, the development of commercial food provision in motorway service stations from 1959, fueled the spread of the ready meal in advance of the acceptance of microwave technology in the 1980s. Along with eating outside of the home, convenience foods are the major trend in food preparation during the twentieth century, in the United States and the UK alike, and both of these trends have been associated with women's increasing participation in paid work outside the home (Lees-Maffei 2013: 125-6).

One response to the increasingly widespread availability of convenience foods was a contrary taste for home-cooked dishes. The desirability of culinary authenticity underpinned Elizabeth David's influential A Book of Mediterranean Food of 1950 and the traditionalism of French Cordon Bleu cookery school alike. Floral designer Constance Spry, and Rosemary Hume, ran a Cordon Bleu cookery school in Britain and published accompanying books on cookery and home entertaining (Spry and Hume, 1956, 1961), just as Julia Child popularized methods she had learned at Le Cordon Bleu in Paris, for an American audience in Mastering the Art of French Cooking, co-authored with Simone Beck and Louisette Bertholle (Beck, Bertholle and Child, 1961). The year after David's Mediterranean Food appeared, the Festival of Britain introduced UK visitors to the milk bar, a café serving milkshakes among other things, which served as a location for teenage sociability, and the Good Food Guide was launched (Lees-Maffei 2013: 126).

Aside from the simplification of menus and the use of convenience foods and buffets, the designers of domestic goods joined architects and home economists in promoting solutions to the 
expanded burden of the unassisted hostess centered upon innovative uses of domestic space, particularly the provision of flexible spaces. New tools facilitated domestic practices that bridged the backstage region of the working kitchen, and the social front of the reception rooms in the home of the 1960s (Lees-Maffei 2007). A basic example is the recommendation of simple, sturdy designs for ceramic or Pyrex oven-to-tableware, which saved time which would otherwise have been spent plating food for presentation on serving dishes. Another practical solution was Tupperware's "Party Susan"; akin to the "lazy Susan," which can be rotated to allow food to be passed between diners, Tupperware's Party Susan featured six compartments for separating foods, a lid to keep food fresh, and a handle which allowed it to be carried between kitchen and buffet. More complex solutions took the form of gadgets and appliances such as electric platewarmers and hot plates. These enabled advanced preparation of food that could be kept hot and freed women performing the dual role of cook-hostess from having to co-ordinate the simultaneous readiness of meal components as well as allowing food to remain warm when left out for guests to help themselves, as noted in the UK Design Council publication, Tableware of 1969:

With smaller houses, better planning of kitchens in relation to eating-serving, and the growing tendency to eat at least some meals in the kitchen, keeping food hot is no longer the problem it was when protocol and several flights of stairs separated kitchen from dining room. Nevertheless there are occasions when equipment for keeping dishes hot can be useful [...] for parties to save constant trips to and from the table (Good 1969: 53).

Plate warmers and hot plates, however, merely preserve what has been achieved in the kitchen. A next step is the use at the table of portable cooking equipment such as "electric skillet, rotisserie 
or a thermostatically controlled cook-and-serve unit" (Woman's Own 1967: 85). These turn the dining area into a temporary kitchen. Similarly, while the standard hostess trolley functions as a bridging device, easing the transition from kitchen to dining room, a more complex model with a hot plate can function almost as a portable kitchen, especially when combined with a small cooking device of the type mentioned.

In advising the unassisted hostess, domestic advisors prescribed modifications to the design and layout of the ideal home, which first bridged front and backstage regions, and then collapsed the distinction between them. Discrete kitchens, sitting rooms and dining rooms, popularized prior to the twentieth century, were bridged with designed goods ranging from ovento-tableware, hot plates, portable cooking appliances and hostess trolleys, and the distinctions between the separate spaces were collapsed through architectural solutions such as the transitional service hatches and a variety of hybrid kitchen and eating spaces like living-dining rooms, kitchen-diners and an open plan [Figure 7.4 near here]. Domestic advisors of the 1960s went further in presenting even more flexible solutions. Joyce Lowrie is not alone in recommending that that the hall be used as "a tiny, formal dining room for grown-ups" (Lowrie 1964: 18). Ilana Henderson's ingenious revolving kitchen is just one of a number of examples (most notable among them Joe Columbo's "Mini-kitchen” of 1963) which negate the existence of the kitchen as a discrete space and redefine it as an object for use in any room (Good 1969: 57). It was developed with Bird's Eye Foods, a collaboration which associates the company with a future of convenience food and the decline of a more traditional ideal kitchen. These novel domestic solutions engage the modernist design virtues of space-saving, flexibility, multifunctionality, informality and practicality. The prevalence of the kitchen-diner by the end of the 1970s constituted a rejection of the upper and middle-class Victorian ideal home, in which 
separate rooms for discrete functions had been enshrined as standard, and resembled much more the experience of working-class Victorians. Thus the period witnessed a return to multi-purpose flexible rooms that preceded the Victorian ideal.

In an era in which broader influences of food preparation and interest in new cuisines encouraged a redefinition of home cooking as creative, the collapse of front and backstage produced a situation of greater visibility and continuous performance for the cook-hostess, thereby increasing her social labor. The design solutions offered promoted the juggling of multiple, competing roles and domestic advice writers thus avoided the more radical and effective proposition that labor might be distributed more equally between the members of the household than the stereotypical and sexist distribution of labor, as discussed in the introduction, allowed. (Lees-Maffei 2007).

\section{Aspirations: Media attention to homes and hospitality, 1970-1990}

Private domestic practices have not been recorded to the extent that public events have, nor have they been as visible. The ways in which hospitality has been practiced and expressed in the relatively private realm of the home is, therefore, difficult for historians and others to access. However, a key distinguishing feature of domesticity in the period from 1920 to the present is the abundance of printed and broadcast sources about the home. The further expansion of print culture in the twentieth century and the introduction of new media technologies such as television, and more recently the internet, have meant that hospitality and home are the subject of significant media attention in books, magazines, radio and television broadcasts, websites, blogs and social media posts. Some figures associated in various ways with the practice of domestic hospitality have attained the status of intertextual reference points—advisors who are referred to 
in the books of other advice writers-from Constance Spry in the postwar UK, to Martha Stewart and Donna Hay in the millennial United States and Australia respectively.

One such reference figure, albeit imagined, who has been instrumental in representing domestic hospitality in 1970s Britain, is the hostess Beverly, from Mike Leigh's play Abigail's Party. The play was first performed at the Hampstead Theatre, London in April and July 1977, and broadcast on television as part of BBC 1 series Play for Today in November of that year. Leigh's satire was developed through improvisation with the cast, including his then-wife Alison Steadman who played Beverly. The stage directions give an insight into the specificity with which the details of Beverly and Laurence's party are captured by Leigh:

Laurence and Beverly's house, the ground floor. Room-divider shelf unit, including telephone, stereo, ornamental fibre-light, fold-down desk and prominently placed bar. Leather three-piece suite, onyx coffee-table, sheepskin rug. Open-plan kitchen, dining area with table and chairs. Hall and front door unseen.

Lights up.

Enter Beverly. She puts on a record (Donna Summer: Love to Love You Baby). Lights a cigarette. Places a copy of Cosmopolitan in magazine rack. Pours a gin-and-tonic. Gets a tray of crisps and salted peanuts from the kitchen and puts it on the coffee table. Sits.

Pause.

Enter Laurence, with executive case. (Leigh 1983 n.p.) [Figure 7.5 near here].

Beverly's party, characterized by "the stifling charade of social etiquette: cocktail napkins, pineapple chunks, and party sausages on sticks, 'nibbles' and 'little fillups,", which ultimately proves fatal for her husband Laurence (Brottman 2007), is compared with the imagined lasciviousness of the off-stage party of neighboring teenager Abigail. The play remains a salient 
study of the pretensions of domestic hospitality and the ways in which the extension of hospitality engages social power dynamics. Reviewing the play for the Sunday Times, writer Dennis Potter railed against Leigh's snobbery, describing the play as “a prolonged jeer, twitching with genuine hatred, about the dreadful suburban tastes of the dreadful lower middle classes." He concluded "As so often in the minefields of English class consciousness, more was revealed of the snobbery of the observers than of the observed" (Potter 1977: 35).

The UK and the United States both took a turn to the right politically during the 1980 s with Margaret Thatcher, British Prime Minister from 1979 until 1990, in a "special relationship" with Ronald Reagan, US President from 1981 to 1989. For those who could afford it, Thatcherism in politics translated into domestic life in terms of an emphasis on home ownership and new conspicuous consumption patterns for the mass middle class (Lees-Maffei 2013: 11). Thatcherism fostered acquisitiveness among a wider proportion of the British market. Workingclass people were actively encouraged to become homeowners through the right-to-buy scheme that depleted Britain's social housing infrastructure, and a (doomed) property boom rewarded existing owner-occupiers. Even the ensuing slump in the property market meant that people focused on improving their current homes and leisure became more home-centered (Lees-Maffei 2014: 291-2).

Aspirations to continental European culinary excellence found expression in the influence of French nouvelle cuisine, an exercise in culinary skill, product freshness and dietary restraint. Nouvelle cuisine attracted satirical responses highlighting the inadequate portion sizes, and influenced mass market convenience foods such as American manufacturer Stouffer's 'Lean Cuisine" brand, introduced in 1981. Research into the obesity epidemic in the West in the later twentieth and early twenty-first centuries has shown that portion sizes at home vary greatly when 
compared with catering industry portioning. In any case, the expression of hospitality which is based on largesse in provisioning was at odds with the reductive approach of nouvelle cuisine and remains so when set against calorie- or otherwise controlled diets which have refusal at their core, rather than acceptance.

The period from 1980 to 1995 epitomizes the extent to which media coverage of homes and hospitality increased throughout the period from 1920 to 2000. In the British magazine market, several new titles were introduced, while circulation figures for existing titles grew. Both What's New in Interiors and House Beautiful reached circulation highs in 1993. Simultaneously, the trade publications Interior Design and Kitchens and Bathrooms increased their circulations by around 50 percent. While Homes and Gardens and Home Improvements Journal fell victim to the increased competition, there was nevertheless a boom period in magazine circulation between 1986 and 1992, indicative of real and increased interest in the home (Lees-Maffei 2014: 292-5).

In 1982, Martha Stewart, today seen as the leading authority on matters of hospitality, published Entertaining, the first of what now amounts to around 100 books on home entertaining and decoration. With a degree in history and architectural history, Stewart worked as a model and then as a Wall Street stock trader before restoring a house in New England. She subsequently set up a catering business, which led to the publication of Entertaining. The style of home entertaining promoted in the 1982 book differs from Stewart's more recent book on the subject, Martha Stewart's Dinner at Home: 52 Quick Meals to Cookfor Family and Friends (2009), with the later book forming yet another exemplar of informalization. Stewart's considerable influence on the homes and hospitality practices of American householders relies on her astonishing reach, in terms both of the breadth of content (entertaining, cooking, 
gardening, interior design) and the multiplicity of platforms. Martha Stewart Living Omnimedia (MSLO) spans publishing, media and merchandising activities, which are woven together in a range of tie-in promotions and licensing deals. Her magazine, television and radio shows, many product lines, and her extensive use of social media mean that Martha Stewart the woman is almost indistinguishable from Martha Stewart the brand.

\section{Millennial hospitality, 1990-2010: Technology and reactions}

Hospitality at home in the final decade of the twentieth century can be characterized as having been dominated by two competing trends: the domestic impact of new technologies, and reactions to that impact. In this sense, the turn of the twentieth century into the twenty-first resembles the fin de siècle one hundred years previously, in which a long process of industrialization in the West had provoked a far-reaching movement of social and design reform that looked to a pre-industrial past for the succor needed to face the new century. Then, protomodernism and high modernism in design influenced the design and decoration of people's homes, if not the behaviors practiced within them. However, in the period leading up to our own century the domestic impact of new technologies and reactions to them has been largely behavioral, rather than impacting the material make-up of the home.

In terms of home design and hospitality, this period therefore represents a continuation of innovations in open plan interiors introduced in the postwar period and given a boost by postindustrial "loft" living in the 1980s and beyond. While open plan living is ostensibly less formal than domestic practices based on the segmentation of space, and through that, the separation of distinct practices and even family members, it is also demanding on hosts and hostesses. Open plan and multi-functional domestic spaces form part of a wider aestheticization of everyday life (Bourdieu 1984) in which all of one's home is available to guests for inspection and judgement. 
Open plan kitchens, flexible kitchen-dining and living-dining spaces provide no refuge for flurried hosts and hostesses and their domestic messes. Happily, however, while the trend in home design — as evidenced by consumer and trade magazines alike—is strongly in favor of open plan homes, in practice millennial householders continue to meld an informal, open plan approach to domestic life with the discrete rooms that many houses provide. In socializing, they move from room to room, using them in a variety of different ways rather than as separate spaces with discrete functions. They follow this pattern both in the secondary market of the existing built environment with existing room arrangements, and in new build developments.

Twenty-first century hospitality at home extends beyond the physical borders of the house. The introduction of relatively affordable hardware for personal computing in the 1990s and the technical developments that allowed for extremely widespread market penetration of mobile phones and, later, smartphones has had a huge impact on the ways in which people conduct their social lives. From video chat services such as Skype, Facetime and a raft of apps, to social media sites such as MySpace and Facebook, these new technologies have enabled people to interact socially with others who are not present, or even known to them. They build, therefore, on the remote social interactions enabled by forerunners of various kinds such as the telegram, telephone, and citizens' band radio (local radio communication in which a number of users share a channel). However, the effect of social media in the home has been more impactful in recent years, as more people, globally, have participated. Today, it is not accurate to regard the home as private, although apparently many people continue to do so. In addition to other members of the household, individual home dwellers engage with friends, colleagues, acquaintances and strangers via social media based in text, image and video, to conduct a range of interactions and relationships from maintaining family ties and sharing common interests to 
pursuing romantic and sexual liaisons. The extent to which this activity stands in for, or replaces, hospitality at home, is variable and currently uncharted. However, in so far as social media allow the initiation and maintenance of relationships in the home as well as outside of it, they do fulfil something of the function of hospitality and home at this time.

As well as facilitating sociability, information technologies have facilitated the exchange of information about homes and hospitality as noted above. Internet users can access a plethora of advice about homes and hospitality via subject-specific blogs, advice from friends, family, colleagues and a wider contact group via social media posts and amateur films, for example on Youtube. Professional content providers such as Martha Stewart's Omnimedia team encourage readers and viewers to post evaluations of the advice offered through Stewart's media empire [Figure 7.6 near here]. With the introduction of web 2.0, the Read-Write web, internet users have begun to publish a vast array of online content, from Facebook profiles, and family snaps on Flickr, to home movies on YouTube, opinions on blogs and product reviews on Amazon. An immense resource has been created, at once intimate and widely seen, which allows unparalleled access into the homes and lives of a billion web users. In the online environment, in which anyone with access to a smart phone or a computer (whether at home, at a library or in an internet cafe) has the potential to become a producer, as well as a consumer, of domestic advice means that the problem is not finding advice, but rather judging its value based on the advisor's expertise.

A range of technological developments changed the way food was presented and sold during this period. Innovations in convenience foods continued, for example with freshly washed bag salads removing the need for the domestic cleaning and preparation of leaves and servicing a trend for healthier, lighter foods. Food manufacturers and restaurateurs alike responded to, and 
shaped, new culinary tastes in the West, such as Pacific Rim and Asian-American fusion foods. In the twenty-first century, food purchasing has shifted online to a significant extent, from bulk buying with the major supermarkets to weekly deliveries from local farmers in "vegetable box" schemes that foreground seasonal produce and cooking from scratch. These online subscription box schemes service a need for time-starved customers who are unable or unwilling to grow their own food, in spite of the exhortations of a number of prominent gardening and food writers to do just that (Don and Don 1999; Oliver 2007). At the same time, this return to seasonal food, increased awareness of nutrition and health issues, and pressing ecological concerns, have combined to make convenience foods and supermarket shopping unattractive for some consumers.

The Slow Food movement, which promotes seasonal local foods, authenticity and heritage, was founded in 1986 in response to a proposed McDonald's fast food restaurant in Rome (Slow Food 1989). It also opposes convenience foods at home. Slow Food's first international congress was held in Venice the following year, and the Slow Food publishing house, Slow Food Editore, was launched at the same time. International branches of the movement followed (Slow Food 2015). Campaigning has centered upon eco gastronomy and the availability of food such as raw milk cheeses, which have suffered from large retailing methods, practices such as pasteurization and associated food safety legislation (Lees-Maffei 2016). Member cities and towns around the world include Korea, South Africa and the United States (Cittàslow 2014), and related "Liveable City" initiatives, for example in San Francisco in California, share similar aims. Improved transport and urban infrastructures facilitate increased sociability, including hospitality at home. Home entertaining has always privileged homemade food, even at the height of the trend of convenience foods (the latter would only have been 
served covertly or apologetically by some hosts and hostesses). Slow food entertaining, however, increases the burden of the host and hostess by demanding daily, local, seasonal shopping in place of bulk buying at supermarkets, and by celebrating home cooked food, however simple or elaborate.

The practice of cooking from scratch further increases the domestic workload for householders, and particularly women. The battery of devices designed to assist food production in the home increases year on year, as manufacturers and retailers continue to promote bread makers, ice cream machines, waffle makers, yoghurt and cheese making equipment for the mass, rather than specialist, markets. Each of these appliances implies a further process to be undertaken in the domestic kitchen, thereby increasing the domestic workload, rather than reducing it, in a manner Ruth Cowan has noted ([1983] 1989). Concern about the amount of time involved in cooking, when people perceive themselves to be too busy to cook, is expressed in a number of cook books. For example Martha Stewart has attempted to show how entertaining, which has traditionally relied on home cooking of labor-intensive meals as expressions of regard for the guests, can be approached in a more relaxed, and less time-consuming way (Stewart 2009).

\section{Conclusion}

Just as homes have changed, so have expressions of hospitality in the home. Notwithstanding a range of technological innovations and shifts in standards of relative formality and informalization examined in this chapter, entertaining at home is still an act of labor, however considerable or inconsiderable, and therein lays its value. To invite someone into your home to experience your hospitality remains an act of esteem embedded in effort, even if the occasion is casual, the food bought-in and the entertainment streamed without forethought. Indeed, in the era 
of digital social media, in which hospitality need not mean actual physical presence in someone's home, and need not mean, therefore, physical co-presence, the instances in which people do physically go to one another's homes to enjoy their hospitality become even more meaningful, regardless of the nature of that hospitality. This chapter has shown that hospitality at home is a complex practice in which the physical and material composition of the home supports or denies the behavioral practices of sociability. Hospitality, in these terms, is nothing less than care manifested socially and materially. In these terms, hospitality at home, in the intimate familial spaces of everyday life, is surely more meaningful than hospitality as it is practiced industrially in hotels, restaurants and other settings, however competent and professional the commoditized affect might be in those settings. 


\section{References}

A Society Lady (1923), The A.B.C. of Etiquette by A Society Lady, London: Drane's.

Albrecht, D., and R. Schonfeld (2001), "Introduction,” in D. Albrecht, R. Schonfeld and L.

Stamm Shapiro (eds), Russel Wright: Creating American Lifestyle, New York: Cooper-

Hewitt, National Design Museum, Smithsonian Institution, Abrams.

Beck, S., L. Bertholle, and J. Child (1961), Mastering the Art of French Cooking, New York: Knopf.

Bourdieu, P. (1984), Distinction: A Social Critique of the Judgment of Taste, Cambridge, MA: Harvard University Press.

Brottman, M. (2007), "Debauchery Next Door: The Boundaries of Shame in Abigail's Party," Quarterly Review of Film and Video, 24 (4): 317-23.

Bullock, N. (1988), "First the Kitchen—then the Façade," The Journal of Design History, 1 (3/4): 177-92.

Cannadine, D. (1990), The Decline and Fall of the British Aristocracy, New Haven and London: Yale University Press.

Cittàslow (2014), “Cittàslow List.” Available online:

http://www.cittaslow.org/download/DocumentiUfficiali/CITTASLOW_LIST_november20 14.pdf (accessed September 5, 2016).

Coveney, J. (2000), Food, Morals and Meanings: the Pleasure and Anxiety of Eating, London: Routledge.

Cowan, R. S. ([1983] 1989), More Work for Mother: the Ironies of Household Technology from the Open Hearth to the Microwave, London: Free Association Books, New York: Basic. David, Elizabeth (1950), A Book of Mediterranean Food, London: Lehmann. 
Don, M., and S. Don (1999), Fork to Fork, London: Conran Octopus.

Edgell, S. (1993), Class, London: Routledge.

Elias, N. (1994 [1939]), The Civilizing Process, vol. 1, The History of Manners, Oxford: Blackwell.

Frederick, C. ([1923] 1919), Household Engineering: Scientific Management in the Home, Chicago: American School of Home Economics.

Giddens, A. (1981), The Class Structure of the Advanced Societies, 2nd edn, London: Hutchinson.

Giddens, A. (1991), Modernity and Self-Identity, Cambridge: Polity Press.

Goffman, E. (1990 [1959]), The Presentation of Self in Everyday Life, London: Penguin.

Goldthorpe, J. H., D. Lockwood, F. Bechhofer, and J. Platt (1968-9), The Affluent Worker, 3 vols., Cambridge: Cambridge University Press.

Good, E. (1969), Tableware, London: Macdonald and Co. in association with the Council of Industrial Design.

Hardyment, C. (1995), Slice of Life: The British Way of Eating Since 1945, London: BBC Books.

Henderson. S. R. (1996), “A Revolution in the Woman’s Sphere: Grete Schütte-Lihotzky and the Frankfurt Kitchen," in D. Coleman, E. Danze, and C. Henderson (eds), Architecture and Feminism, 221-253, New York: Princeton Architectural Press.

Hochschild, A. R. (1983), The Managed Heart: The Commercialization of Human Feeling, Berkeley: University of California Press.

James, N. (1989), "Emotional Labor: Skill and Work in the Social Regulation of Feelings," The Sociological Review 37: 15-42. 
Lees-Maffei, G. (2001), "From Service to Self-Service: Etiquette Writing as Design Discourse 1920-1970,” The Journal of Design History, 14 (3): 187-206.

Lees-Maffei, G. (2007), “Accommodating 'Mrs. Three-in-One’: Homemaking, Home Entertaining and Domestic Advice Literature in Post-war Britain," Women's History Review, 16 (5): 723-54.

Lees-Maffei, G. (2010), “Introduction, War/Post-War/Cold War, 1943-70,” in G. Lees-Maffei and R. Houze (eds), The Design History Reader, 129-33, Oxford: Berg.

Lees-Maffei, G. (2013), Design at Home: Domestic Advice Books in Britain and the USA since 1945, Directions in Cultural History, Abingdon: Routledge.

Lees-Maffei, G. (2014), “"Made’ in England? The Mediation of Alessi S.p.A.,” in G. LeesMaffei and K. Fallan (eds), Made in Italy: Rethinking a Century of Italian Design, 287303, London: Bloomsbury.

Lees-Maffei, G. (2016), “'Why then the world's mine oyster': Consumption and Globalization 1851-Now," in P. Sparke and F. Fisher (eds), The Routledge Companion to Design Studies, 445-456, London: Routledge.

Leigh, M. (1983), Abigail's Party and Goose Pimples, London: Penguin.

Lowrie, J. (1965), Practical Homemaking, London: Oldbourne.

Lynes, R. (1980 [1949]), The Tastemakers: The Shaping of American Popular Taste, New York: Dover.

Merivale, M. (1944 [1938]), Furnishing the Small Home, London: The Studio.

Mills, C. W. (1999 [1956]), The Power Elite, New York: Oxford University Press.

Oddy, D. J. (2003), From Plain Fare to Fusion Food: British Diet from the 1890s to the 1990, Woodbridge: Boydell Press. 
Ohmann, R. (1996), Selling Culture: Magazines, Markets and Class at the Turn of the Century, London and New York: Verso.

Oliver, J. (2007), Jamie at Home: Cook Your Way to the Good Life, London: Michael Joseph.

Post, E. (1922), Etiquette in Society, in Business, in Politics and at Home, New York: Funk and Wagnalls.

Potter, D. (1977), “Trampling the Mud from Wall to Wall," review of Abigail's Party in The Sunday Times, November 6, 35.

Reid, S. E. (2005), “The Khrushchev Kitchen: Domesticating the Scientific-Technological Revolution," Journal of Contemporary History, 40 (2): 289-316.

Robertson, H. (1947), Reconstruction and the Home, London: The Studio.

Schlesinger, A. M. (1968 [1946]), Learning How to Behave: A Historical Study of American Etiquette Books, New York: Cooper Square and Macmillan.

Slow Food (2015), Available online: http://www.slowfood.com/about-us/our-history/ (accessed September 5, 2016).

Spry, C. (1942), Come Into the Garden, Cook, London: J.M. Dent and Sons.

Spry, C. and R. Hulme (1956), Constance Spry Cookery Book, London: J. M. Dent and Sons (reissued London: Pan Books, 1972 and 1979).

Spry, C. and R. Hume (1961), Hostess, ed. Anthony Marr, London: J. M. Dent and Sons.

Stewart, M. (1982), Entertaining, New York: Clarkson Potter.

Stewart, M. (2009), Martha Stewart's Dinner at Home: 52 Quick Meals to Cook for Family and Friends, New York: Clarkson Potter.

Strasser, S. (2000 [1982]), Never Done: A History of American Housework, New York: Henry Holt. 
Veblen, T. (1970 [1899]), The Theory of the Leisure Class: an Economic Study of Institutions, intro. C. Wright Mills, London: Unwin Books.

Woman's Own (1967), The Woman's Own Book of Modern Homemaking, London: George Newnes.

Wouters, C. (2007), Informalization: Manners and Emotion since 1890, London: Sage.

Wright, M., and R. Wright (1954 [1950]), Guide to Easier Living: 1,000 Ways to Make Housework Faster, Easier and More Rewarding, rev edn, New York: Simon and Schuster. Young, L. (2003), Middle-Class Culture in the Nineteenth Century: America, Australia and Britain, Basingstoke: Palgrave Macmillan. 